\title{
Implementation of Hybrid Genetic Algorithm for CLSC Network Design Problem-A Case Study on Fashion Leather Goods Industry
}

\author{
Muthusamy Aravendan', Ramasamy Panneerselvam² \\ ${ }^{1}$ Department of Leather Design (Footwear \& Products), National Institute of Fashion Technology, \\ Chennai, India \\ ${ }^{2}$ Department of Management Studies, School of Management, Pondicherry University, Pondicherry, India \\ Email: aravendan@yahoo.com, panneer_dms@yahoo.co.in
}

Received 30 April 2016; accepted 10 July 2016; published 13 July 2016

Copyright (C) 2016 by authors and Scientific Research Publishing Inc.

This work is licensed under the Creative Commons Attribution International License (CC BY). http://creativecommons.org/licenses/by/4.0/

(c) (i) Open Access

\begin{abstract}
The implementation of closed loop supply chain system is becoming essential for fashion leather products industry to ensure an economically sustainable business model and eco-friendly industrial practice as demanded by the environmental regulations, consumer awareness and the prevailing social consciousness. In this context, this research work addresses a closed loop supply chain network problem of fashion leather goods industry, with an objective of minimizing the total cost of the entire supply chain and also reducing the total waste from the end of life product returns. The research work commenced with a literature review on the reverse and closed loop supply chain network design problems of fashion and leather goods industry dealt in the past. Then, the identified CLSCND problem is solved using a mathematical model based on Mixed Integer Non-Linear Programme (MINLP) and then a suitable Hybrid Genetic Algorithm (HGA) developed for the CLSCND is implemented for obtaining optimum solution. Both the MINLP model and HGA are customized as per the CLSCND problem chosen and implemented for the industrial case of an Indian Fashion Leather Goods Industry. Finally, the solutions obtained for MINLP model in LINGO 15 and for HGA in VB.NET platform are compared and presented. The optimum solution obtained from the suitable HGA is illustrated as an optimum shipment pattern for the closed loop supply chain network design problem of the fashion leather goods industry case.
\end{abstract}

\section{Keywords}

Industry Case, CLSC, Fashion Products, Leather Goods, Luggage Goods, Hybrid Genetic Algorithm (HGA), Meta-Heuristics, MINLP, Network Design, Reverse Supply Chain 


\section{Introduction}

The Indian leather goods, luxury and fashion accessories industries are exhibiting growth and encouraging global presence in recent times. Across the Country, the manufacturing capacity has been built up by the fashion industries. The companies are producing and supplying highly innovative, fashionable and lifestyle products like fashion hand bags, business folios, travel goods, luggage goods etc., in varieties both for domestic and export markets. As the consumer preference is drastically changing according to their changing lifestyles, buying capacities and consumption pattern, the companies have been registering consistency in increased sales and market demand especially in the fashion life style products, personal accessories, travel, luggage and leather goods categories. The invasion of international brands and exposure of domestic consumers to the global fashion play a significant role in the buying behaviour and influencing the frequent changes in consumer preferences. As a result, the consumers are seeking variety of products in short periods to fulfil their psychological demands and desires. The modern fashion conscious consumers buy the fashion goods for the festival seasons, frequent domestic and international travels, vocational tours, and other ceremonial occasions like wedding, traditional and cultural functions, special get-together parties, and even for formal, casual occasions etc. The domestic market demand is increasing in higher-end products, including fashionable travel \& luggage goods, leather hand bags, and other life style products. Across the channels, several new ranges were launched in all brands and price points, in both leather and non-leather products categories with a special thrust on business collections, semi-formal products, and fashionable travel and luggage goods.

This increasing demand and variety seeking consumers approach lead to the supply of fashion products with short product life cycles and rapid product returns. Huge demand for variety of styles in small orders leads to increase the cost of entire supply chain, shortage of raw materials, and increase in wastage of end of life products. The consumption and end of life return of the short lived products like travel \& luggage goods, fashion leather accessories, hand bags are in the upward trend in the domestic as well as international markets. This increase in product returns poses a great challenge to the industries and the environment to manage these returns for sustainable business and living conditions. Also, due to the increase in the price and decrease in the supply of virgin raw materials and components, enforcement of eco-friendly regulations by the government, the companies are facing difficulties in manufacturing and marketing new and fresh products at a very competitive and affordable price to the consumers. The fashion and lifestyle product companies are looking into alternate sources of raw materials, assemblies, components to produce and supply to both primary and secondary market segments. To address this important issue, the integration of the forward supply chain and reverse supply chain is very essential and proven in other industries especially in automobile, consumer electronics etc. Similar strategy shall be encouraged and implemented for the fashion, life style and leather products also to solve the above said problems. So, developing a suitable integrated supply chain model with appropriate problem solving methodology and corresponding implementation strategies are essential and are identified as the thrust area of this research work.

Based on this background of research, the closed loop supply chain model and the suitable algorithm developed by the researchers Aravendan and Panneerselvam [1] [2] are very much in need and would be beneficial for addressing the closed loop supply chain network design problems in the fashion product industries particularly in fashion leather goods industries. To validate and propose the implementation of the model and algorithm developed, the researchers approached few industries that are inclined towards implementing the closed loop supply chain strategies for solving the network design problem of their industries. According to the extent of interest shown and support provided, a fashion leather goods industry has been considered by the researchers for implementing the MINLP model and meta-heuristics (HGA) developed. Thus, this research paper deals with an industrial case study and implements the model, and suitable HGA for solving the CLSC network design problem in a real life situation in the fashion leather goods industry, which manufactures and supplies travel bags, luggage goods and leather hand bags to the domestic consumers and located at Mumbai, in the state of Maharashtra, in India.

The research paper is structured as follows. In the next section, the supply chain network design problems like reverse and closed loop supply chain problems dealt in the past research works for fashion and leather goods industry sector are presented through a literature review. In the section three, the research objectives and problem statement of the research work formulated by identifying the research gaps are presented. The fourth section discusses the right research methodology for implementing the research work. The industry case study is de- 
scribed in the fifth section with the model description, implementation of the model and hybrid genetic algorithm developed with the end results which gives an optimum solution for the CLSC network design problem. The solution is illustrated as the shipment pattern for the identified problem of the leather goods industry case. The paper ends with the concluding remarks with the summary of findings.

\section{Supply Chain Network Design Problems in Fashion Leather Goods Industry}

The research works on the supply chain network design models and algorithms for solving the closed loop and reverse supply chain network design problems for the past two decades are surveyed and reviewed by the researchers. The applications of the reverse and closed loop systems are very less and at the primitive stage in the fashion product sectors particularly in the leather goods industries. The literatures thus reviewed are presented in this section.

\subsection{Literature Review}

Fleischmann et al. [3] presented a review of recent case studies initially and identified generic steps of activities carried out in product recovery networks. They recognized two parts in the product recovery process, viz. a convergent part which collects the products from the customers and a divergent part which dispose the recovered products after reprocessing. Bruce et al. [4] considered the application of various supply chain models, viz. Lean, Agile and Le-Agile in the textile and clothing industry. They applied exploratory and case study methods to execute their researches. The secondary data and primary data collected via semi structured interviews were used to build the cases of four textile and clothing industries, viz. fashion apparel manufacturer, fabric manufacturer, an accessory design firm dealing with sportswear and a brand manufacturer. The research outcome shows that the companies in the textile and apparel sectors use both lean and agile supply chain systems due to prevailing nature and characteristics of the textile and apparel industries due to the short life cycle of the products, low cost of manufacture, reduced prices demanded by the retailers and the volatility of the consumer demands. Barnes and Greenwood [5] presented their research on the application of supply chain system for the fast fashion requirements. The researchers collected the data through in depth interview with the respondents from the fashion industry. They demonstrated the supply chain systems of fast fashion industry and presented the research agenda for future explorations. They also threw insights into the effect of the short lived fashion products on the supply chain and retail operation as the industry is entirely driven and influenced by the consumers. Li and Olorunniwo [6] presented the case study of three companies for exploring the reverse supply chain systems. The researchers dealt with the generic reverse logistics process flow, application of process technology and information technology that a firm needs in order to operate an effective RL system. Ho and Choi [7] presented a Five-R analysis for sustainable fashion supply chain management in Hong Kong with case analysis. The researchers applied exploratory qualitative method to propose and apply the Five-R analysis in the real case which includes five critical processes, namely recycle, reuse, reduce, re-design and re-imagine. Nie $\boldsymbol{e t}$ al. [8] developed three closed-loop supply chain models, where manufacturers can utilize financial or physical support to push a third party to collect the used fashion product for remanufacturing. They first examined two strategies for the collective recycling responsibility (CRR), namely the financial sharing (FS) and the physical sharing (PS) by using the model with no CRR as a benchmark. Then they conducted a detailed comparison among the three models in terms of the retail price, demand, return rate, and the profits received by the supply chain members.

Ciarniene and Vienazindiene [9] presented theoretical model illustrating supply chain management of modern fashion industry, which has fast-moving and trend-driven business involving three sectors of economy and four tiers of the supply chain. They observed that the fashion supply chain systems are characterized by three critical lead-times, which are time-to-market, time-to-serve and time-to-react, which stress the importance of agility in fashion supply networks. Aravendan and Panneerselvam [1] considered a multi-echelon closed loop network design problem with an objective to minimize the total cost of the network and increasing the quality of service. They developed a mixed integer non-linear programming model to solve the CLSCND problem. The researchers simulated the experiments and solve the model using the optimization software LINGO14. Tokhmehchi, et al. [10] developed a hybrid approach to solve a model of closed loop supply chain, which includes plants, demand centers, collection centers and disposal centers. They proposed a mixed integer programming model for this problem to minimize the total cost. The researchers used four types of meta-heuristics, which are 
hybrid forms of genetic and firefly algorithms and analyzed the performance of the algorithms by generating adequate number of instances. The results show that hybrid algorithms provide better solution than that provided by other approaches for large size problems. Aravendan and Panneerselvam [2] presented four different hybrid genetic algorithms (HGAs) for network design problem in closed loop supply chain. The researchers compared the four HGAs using a complete factorial experiment with two factors, viz. problem size and algorithm and identified the best algorithm using Duncan's multiple range test. Then they compared the best HGA with their mathematical model in terms of total cost and found that the best hybrid genetic algorithm identified gives results on par with the mathematical model in statistical terms for small and medium size problems and also provides faster solution to large size problems. The model and algorithm developed can be applicable to a range of industries like Fashion \& Clothing, Footwear \& Leather, Consumer Electronics, Automobiles, Lifestyle and luxury products industries etc.

\subsection{Research Gaps}

The past literature of the network design problems of the closed loop supply chain system and reverse supply chain system in the Fashion and Leather Goods Industry is thus reviewed and presented. The authors found that in the earlier research works, the researchers applied models, heuristics, genetic algorithms and hybrid GAs, etc. to solve the supply chain network design problems. The application of the models and heuristics for solving the closed loop and reverse supply chain network problems in the fashion products sectors like fashion travel goods, luggage and leather goods industry are rare or less in practice as the problems are combinatorial and NP-hard in nature. A very few developed countries where the environmental legislations are very stringent, employ these systems to adhere to the environmental and legal norms. As the problem is universal and existing globally, the industries are to be educated and awareness should be created for implementing these integrated systems and models for solving the supply chain network design problems. Thus, it is very much essential for the fashion leather goods industries to focus and implement the integrated closed loop supply chain systems in order to sustain in the business with the growing problems of shortage of raw materials like leathers and non-leather materials, accessories and other hardware etc. to cater to the domestic demands and adhere to the norms of the pollution control measures, environmental regulations and legislations being under enforcement by the government.

\section{Statement of the Research Problem and Research Objectives}

With reference to the research gaps identified, the research problem of the fashion leather goods industry case has been considered and stated here. The research objectives are formulated to implement the problem solving methods of the CLSC network design problem of the leather goods industry. The research problem and the research objectives thus formulated are presented in this section.

\subsection{Statement of the Research Problem}

The research problem formulated for the identified industry case has the primary objective to develop a suitable hybrid genetic algorithm to minimize the total cost of the closed loop supply chain network design. The CLSC network design model considered in this research work is an integrated forward and reverse supply chain networks which consists of leather goods brand manufacturers, leather goods brand dealers, leather goods brand retailers and first customers in the forward distribution channel. The reverse distribution channel consists of leather goods service/repair centers, products collectors/dismantlers/re-furbishers (CDR), leather goods brand remanufacturers, product recyclers, waste disposal centers/land-fillers, leather goods brand resellers and second customer. The fashion leather products returned by the first customers are divided into repair products and end-of-life or end-of use products for reprocessing and distributing in the reverse channel. The leather goods for repairing works are received directly from the customers by the repair centers and returned to them after repairing. The end-of-use or end-of life leather goods are collected from the first customers either directly from the customers or through the leather goods brand retailers or through both the options as applicable. The returned leather goods collected by CDR locations are assessed and assorted according to their conditions. Then they are grouped into batches as refurbishable products, components recoverable products, non-recoverable or waste products. The refurbishable products are reconditioned and sent to the leather goods brand resellers. The components recoverable products are dismantled with the components and the parts are supplied to leather goods 
remanufacturers and recyclers for utilizing them remanufacturing and recycling operations. The non-recoverable products and components are then treated as waste materials and supplied to the waste disposal centers or land-fillers for getting them disposed by either incineration or land filling in the dump yards allotted for the purpose. The remanufactured leather goods are delivered to the customers in the secondary market through the leather goods brand resellers. The recyclable components are collected by the raw material suppliers for converting and resupplying as lesser grade raw materials for making secondary products. The demand and supply of each channel partner in the CLSC network design are determined and certain. Thus, this CLSCND model is considered as the single product, single period, and multi-echelon model with integrated strategy of forward and reverse supply chains in order to minimize the total cost of the supply chain network and also ensure economic and environmental sustainability during the implementation of the system.

\subsection{Statement of the Research Objectives}

The problem identified for the closed loop supply chain network design model of the fashion leather goods industry is solved by formulating and achieving the objectives by the researchers which are furnished below:

1) To implement the mathematical model at the first instance to obtain an optimal solution for the identified CLSCND problem of the fashion leather goods industry. If the mathematical model does not solve the problem of the industry case, then apply the best hybrid genetic algorithm to solve the problem of the leather goods industry case.

2) To implement the best hybrid genetic algorithm for solving the supply chain network design model problem of the fashion leather goods industry and obtain an optimum or nearby optimum solution for minimizing the total cost of the entire CLSC network with an illustration of the optimized shipment pattern.

\section{Adaptation of Research Methods}

The nature and type of the closed loop supply chain network model and the problem identified require the application of combination of research methods. The main research methods applied in this research work are Mathematical Modeling, Algorithmic research and Case Study research methods. The mathematical model is adopted from the research work presented by Aravendan and Panneerselvam [1]. The model belongs to MINLP class and was developed by referring the mathematical modeling concepts presented in Panneerselvam [11] and the algorithmic research is implemented by adopting the best hybrid genetic algorithm (HGA4) developed by Aravendan and Panneerselvam [2] by referring the GA concepts presented in Panneerselvam [12]. The mathematical model and the best hybrid genetic algorithm thus developed are implemented for CLSC network design problem of the fashion leather goods industry in India. The required secondary data of the company were collected through various reports, documents and websites. The primary data required as inputs for the mathematical model and hybrid genetic algorithm were collected by interviews and surveys among the stakeholders of the company. Then the input data were applied in the model and algorithm for conducting the experiments. The mathematical model was experimented using LINGO 15 and the hybrid genetic algorithm coded in C\# was experimented using VB.NET and Microsoft SQL servers and the results are summarized.

The researchers are bound by the confidentiality agreement between the company and researchers for not disclosing the basic identities of the company. Therefore, the researchers used a dummy company name for the industrial case study discussed in this section. All the data collected with respect to the company are used purely for academic and research purpose and not used for any commercial purpose.

\section{The Case of Travel, Luggage \& Leather Goods Industry}

India is the fifth largest global exporter of leather goods and accessories with an annual production capacity of 63 million pieces of leather articles. The leather goods industry accounts for 25\% share of India's total exports. This capacity building and strong manufacturing establishments enable Indian leather goods industry sector to flourish in the domestic market also. Among the wide range of leather goods supplied to the domestic market, the Travelling, Luggage and Leather Hand Bags are the most demanded and convenient goods used for carrying the belongings such as clothes, daily-use articles and other essentials during travel from one place to other, for office use and other utilities. Although, these products are manufactured from various types of materials such as textile, jute, coated fabrics, yet leather travelling and luggage goods are having wider acceptance due to its supe- 
rior strength, aesthetic look and workmanship among middle and high-income segment customers. The cost of the leather bags depends upon the type of leather, space and/or style of it. The domestic consumption of the leather and non-leather travelling and luggage goods is increasing day-by-day in tune with the growth of industrialization, growing economic standards and lifestyle of people, tourism and fashion consciousness. The important customers of such products are medium and high-income group people belonging to service, business and executive classes. The non-branded products are available with a price range of Rs. 1500 to Rs. 3000 and branded products are available with a wider price range of Rs. 3000 to Rs. 9000 in the Indian market.

Like any other fashion product industry sector, the leather goods industry sector also facing the challenges of dealing with the growing end-of-life product returns and post-consumer wastes due to the consumption of short lived goods by the domestic consumers. Awareness is created among these industries on the environmental regulations and the sustainable supply chain systems to ensure the ecological balance and economically sustainable business by minimizing the total cost of the supply chain system. This leads to the business situations, where the companies have taken serious measures in implementing the appropriate cost effective supply chain systems to tackle the supply chain network design problems. This could be achieved by managing the EOL product returns and post-consumer wastes efficiently through an integrated forward and reverse supply chains in a closed loop distribution network design in the travel, luggage and leather goods industry in India. In this context, a travel, luggage and leather goods industry in the state of Maharashtra is considered as a case study to solve its closed loop supply chain network design problem

\subsection{Introduction to "TLG Industries Pvt. Ltd."}

TLG Industries Ltd is a flagship company of a very big industry group in Maharashtra established in the early 70s. So far the Industry has sold several million pieces of travel, luggage and leather goods to people around the world and subsequently become the foremost manufacturer of hard and soft luggage goods in Asia. The company manufactures an array of products and provides numerous different services with the aim to make travel simple and convenient for millions of people around the country. The Product Portfolio of TLG Industries Ltd. consists of a wide range of hard and soft luggage goods, which includes trolleys, suitcases, duffel-bags, backpacks, executive cases, overnight travel bags, hand bags and school bags. The product range is developed using both leather and non-leather materials. The Company's products continue to enjoy a preferred position in consumer segment particularly in Northern, Western and Southern India, where it has a major share in the industries and hire markets. Soft luggage continues to grow faster than hard luggage and constitutes over 70\% of the Company's sales. The only category in hard luggage which is experiencing growth is the polycarbonate category. Polycarbonate matches the convenience and features that consumers find in soft luggage, that is lightness and four wheeling. "TLG” brand continues to dominate Indian luggage market with the largest market share of all luggage brands in India. The company is now expanding its product range into daily use products such as business bags and backpacks. These categories saw tremendous growth as the company increased its focus in these categories. The company has set up four manufacturing plants at the industrial estates in and around Mumbai. The company successfully launched ladies hand bags category in the year 2012. These bags along with the travel and luggage goods are now available at more than 500 points of sale across the country and distributed through the various channels including select company-run exclusive stores, franchisee stores, and multi-brand dealers and leading departmental chains like Shoppers Stop, Lifestyle and Central as well as e-commerce platforms.

\subsection{CLSC Network Design Model for "TLG Industries Pvt. Ltd."}

The fashion leather goods industry has been proposed with the implementation of the closed loop network design model in order to minimize the total supply chain cost of the integrated network and also to reduce the wastage of end of life or end of use short lived leather and luggage goods returned by the end customers. Thus the CLSCND model proposed is the deemed fit model for the industry case identified for this research work. The description of the CLSCND model is presented as follows.

\subsection{Description of the CLSC Network Design Model}

The closed loop supply chain network design model proposed for solving the problem of the fashion leather goods industry case is the integrated network of forward and reverse supply chain distribution channels. The model has the objective of minimizing the total cost of the integrated supply chain system deals with single 
product in single period. The model consists of leather goods manufacturers, leather goods brand dealers, leather goods brand retailers and first customers in the forward chain and consists of repair/service centers, collectors/dismantlers/re-furbishers, leather goods remanufacturers, recyclers, land fillers, and leather goods brand resellers and second customers in the reverse chain as illustrated in Figure 1.

\subsection{Conditions and Limitations of CLSCND Model}

The proposed CLSCND model is considered with the following conditions and limitations:

1) The CLSCND model of the fashion leather goods industry deals with single product and single period network design problem.

2) All the facilities/channel partners are located in the known places with known destinations and sources with known demand and supply of the goods.

3) The shipment between the partners at the same stage or level is restricted and the quantity of the leather goods returned is known and certain.

4) The proportion of the leather goods returned as EOL goods is $50 \%$ of the total quantity of leather goods supplied and is accounted for reverse process.

5) The proportion of the leather goods returned for repair is $40 \%$ of the total quantity of the leather goods supplied and are returned back to the customer after repairing for reuse.

6) The proportion of the leather goods not returned by the end customers is $10 \%$ of the total quantity of the leather goods supplied to the customers.

7) The proportion of the EOL goods returned to CDR location through leather goods retailers is $40 \%$ of the total EOL goods and the remaining $60 \%$ of the EOL goods are returned directly, to the Collectors/Dismantlers/ Re-furbishers (CDR).

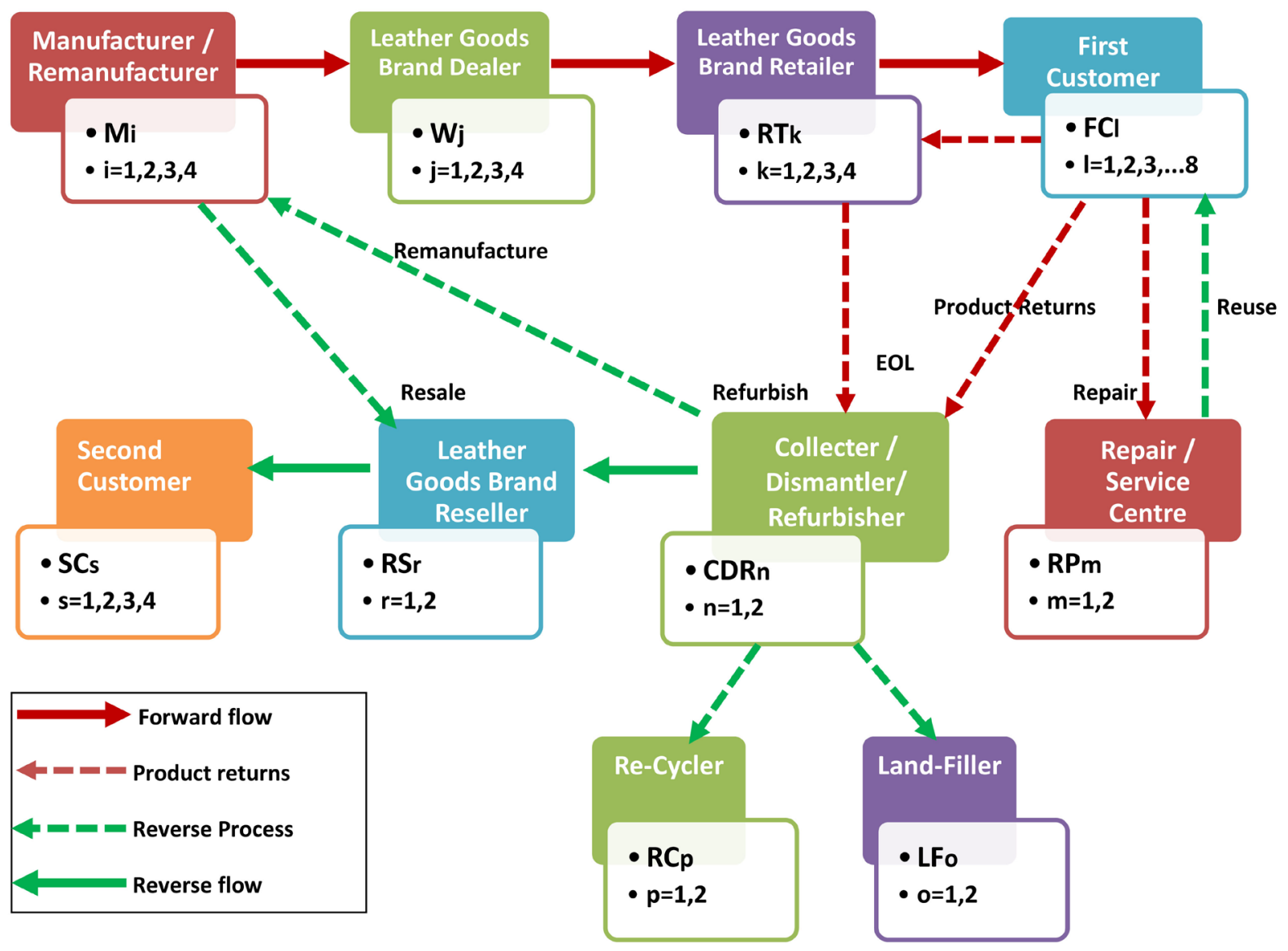

Figure 1. The CLSCND model proposed for the leather goods industry case study. 
8) Out of the total EOL products returned, $20 \%$ of them are refurbishable items, $40 \%$ of them are remanufacturable items, $25 \%$ of them are recyclable items and $15 \%$ of them are non-recoverable and disposed by landfillers.

9) The quality of the remanufactured, refurbished and repaired products is different from that of the new products.

10)The locations of leather goods manufacturers, leather goods brand dealers, leather goods brand retailers, collectors/dismantlers/re-furbishers, repair/service centers, recyclers, land fillers and leather goods brand resellers and their capacities are known.

11)The costs parameters considered, viz. opening costs, operating costs, un-utilized capacity costs and transportation costs are known for all the facilities and nodes.

12)The measure of quantity of products transported per trip is defined in the form of number of units per trip.

\subsection{CLSC Network Design-Demonstration of the Model and Hybrid Genetic Algorithm}

In this section, problem of the closed loop supply chain network design of the leather goods industry is solved by demonstrating the mathematical model and the appropriate hybrid genetic algorithm and the implementation process are presented.

The CLSCND model developed for the travel, luggage and leather goods industry is a single period, single product and multi-echelon closed loop supply chain network design model. It has four echelons, viz. four leather goods manufacturers, four leather goods brand dealers, four leather goods brand retailers, eight first customers in the forward chain and five echelons in the reverse chain, viz. two repair centres, two collectors/dismantlers/refurbishers (hybrid), two recyclers, two land-fillers, four re-manufacturers (hybrid), two leather goods brand resellers and four second customers in the reverse chain as shown in Table 1. The data collected on various model parameters pertaining to the nodes/channel players at the different echelons in the CLSC model are given in Table 2. The maximum number of the channel players or facilities or nodes at the different stages of the integrated closed loop supply chain network and the shipment flows between the pair of facilities or nodes are illustrated in Figure 2.

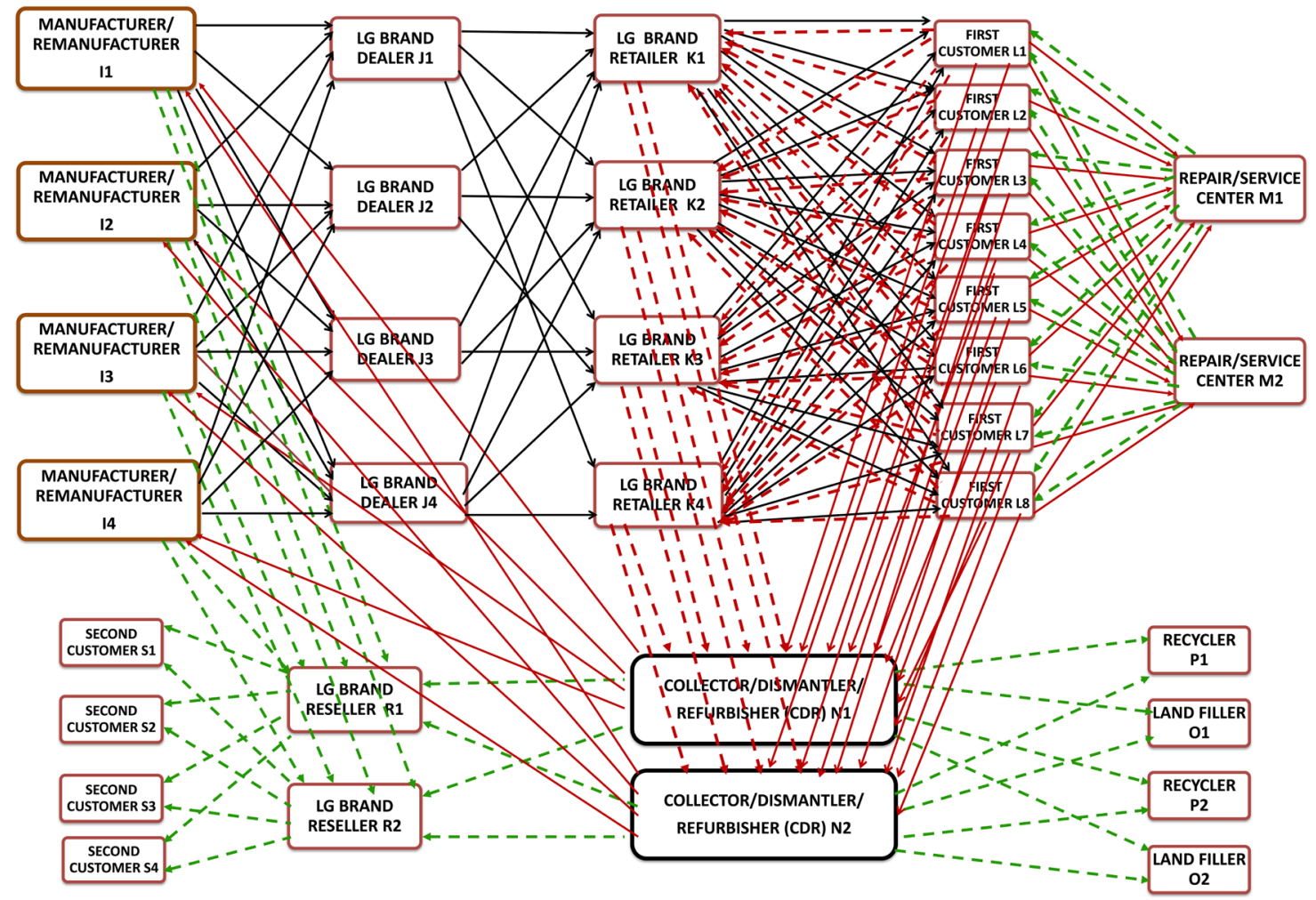

Figure 2. Shipment flows in CLSCND model for the leather goods industry case study. 
Table 1. Facilities and nodes in the CLSC network design model for leather goods industry case study.

\begin{tabular}{cccc}
\hline Facilities/Nodes & No. & Facilities/Nodes & No. \\
\hline $\begin{array}{c}\text { Manufacturers/Remanufacturers } \\
\text { (Hybrid Centres) }\end{array}$ & 4 & $\begin{array}{c}\text { Collectors/Dismantlers/ } \\
\text { Re-Furbishers (Hybrid Centres) }\end{array}$ & 2 \\
Leather Goods Brand Dealers & 4 & Leather Goods Brand Resellers & 2 \\
Leather Goods Brand Retailers & 4 & Recycler (3PL) & 2 \\
First Customers & 8 & Land-Filler (3PL) & 2 \\
Repair/Service Centres (3PL) & 2 & Second Customers & 4 \\
\hline
\end{tabular}

Table 2. Numerical data for model parameters and variables in leather goods industry case study.

\begin{tabular}{|c|c|}
\hline Parameters/variables & Value \\
\hline Unit price of virgin/first products $\mathrm{UP}_{1}, 100 \%$ & Rs. 6000 \\
\hline Unit price of second products $\mathrm{UP}_{2}, 50 \%$ of $\mathrm{UP}_{1}$ & Rs. 3000 \\
\hline Total Demand of first customer D1, 100\%, & 180,000 pcs \\
\hline Total Demand of second customer D2, 35\% of D1 & 63,000 pcs \\
\hline Max return ratio of total EOL product returns to CDR, FCDF $\mathrm{EOLR}_{\text {, }} 50 \%$ of D1 & 90,000 pcs \\
\hline Max return ratio of EOL returns to CDR via Retailer, $\mathrm{EOLF}_{\mathrm{RT}}, 40 \%$ & 36,000 pcs \\
\hline Max return ratio of EOL returns directly to CDR, EOLF $\mathrm{CDR}-60 \%$ & 54,000 pcs \\
\hline Max return ratio of repair products $\mathrm{FCDF}_{\mathrm{RR}}, 40 \%$ of $\mathrm{D} 1$ & 72,000 pcs \\
\hline Land filling fraction CDRF1, 10\% of FCDF $F_{E O L R}$ & 9000 pcs \\
\hline Recycling fraction CDRF2, 20\% of FCDF EOLR & 18,000 pcs \\
\hline Refurbishing fraction (to Reseller) fraction CDRF3, 30\% of $\mathrm{FCDF}_{\mathrm{EOLR}}$ & 27,000 pcs \\
\hline Remanufacturing fraction CDRF4, $40 \%$ of FCDF $F_{\mathrm{EOLR}}$ & 36,000 pcs \\
\hline Capacity of manufacturer-1 & 50,000 pcs \\
\hline Capacity of manufacturer-2 & 50,000 pcs \\
\hline Capacity of manufacturer-3 & 50,000 pcs \\
\hline Capacity of manufacturer-4 & 50,000 pcs \\
\hline Capacity of leather goods brand dealer-1 & 45,000 pcs \\
\hline Capacity of leather goods brand dealer-2 & 45,000 pcs \\
\hline Capacity of leather goods brand dealer-3 & 45,000 pcs \\
\hline Capacity of leather goods brand dealer- 4 & 45,000 pcs \\
\hline Capacity of leather goods brand retailer- 1 & 45,000 pcs \\
\hline Capacity of leather goods brand retailer-2 & 45,000 pcs \\
\hline Capacity of leather goods brand retailer-3 & 45,000 pcs \\
\hline Capacity of leather goods brand retailer- 4 & 45,000 pcs \\
\hline Capacity of collector/dismantler/re-furbisher (CDR) $(25,000 \times 2)$ & 50,000 pcs \\
\hline Capacity of repair/service centre $(36,000 \times 2)$ & 72,000 pcs \\
\hline
\end{tabular}




\section{Continued}

\begin{tabular}{|c|c|}
\hline Parameters/variables & Value \\
\hline Capacity of re-furbisher $(13,500 \times 2)$ & 27,000 pcs \\
\hline Capacity of re-manufacturer-1 & 10,000 pcs \\
\hline Capacity of re-manufacturer-2 & 10,000 pcs \\
\hline Capacity of re-manufacturer-3 & 10,000 pcs \\
\hline Capacity of re-manufacturer-4 & 10,000 pcs \\
\hline Capacity of leather goods brand reseller-1 & 31,500 pcs \\
\hline Capacity of leather goods brand reseller-2 & 31,500 pcs \\
\hline Capacity of recycler- 1 & 9000 pcs \\
\hline Capacity of recycler-2 & 9000 pcs \\
\hline Capacity of land-filler-1 & 4500 pcs \\
\hline Capacity of land-filler-2 & 4500 pcs \\
\hline Opening costs/pce for manufacturer 1 & Rs. 1000 \\
\hline Opening costs/pce for manufacturer 2 & Rs. 1200 \\
\hline Opening costs/pce for manufacturer 3 & Rs. 1500 \\
\hline Opening costs/pce for manufacturer 4 & Rs. 1300 \\
\hline Opening costs/pce for leather goods brand dealer 1 & Rs. 500 \\
\hline Opening costs/pce for leather goods brand dealer 2 & Rs. 400 \\
\hline Opening costs/pce for leather goods brand dealer 3 & Rs. 300 \\
\hline Opening costs/pce for leather goods brand dealer 4 & Rs. 400 \\
\hline Opening costs/pce for leather goods brand retailer 1 & Rs. 200 \\
\hline Opening costs/pce for leather goods brand retailer 2 & Rs. 220 \\
\hline Opening costs/pce for leather goods brand retailer 3 & Rs. 200 \\
\hline Opening costs/pce for leather goods brand retailer 4 & Rs. 200 \\
\hline Opening costs/pce for repair/service centre 1 & Rs. 100 \\
\hline Opening costs/pce for repair/service centre 2 & Rs. 100 \\
\hline Opening costs/pce for collector/dismantler/re-furbisher 1 & Rs. 200 \\
\hline Opening costs/pce for Collector/dismantler/re-furbisher 2 & Rs. 180 \\
\hline Opening costs/pce for remanufacturer 1 & Rs. 450 \\
\hline Opening costs/pce for remanufacturer 2 & Rs. 470 \\
\hline Opening costs/pce for remanufacturer 3 & Rs. 500 \\
\hline Opening costs/pce for remanufacturer 4 & Rs. 450 \\
\hline Opening costs/pce for recyclers & Rs. 100 \\
\hline Opening costs/pce for leather goods brand resellers & Rs. 120 \\
\hline
\end{tabular}




\section{Continued}

Parameters/variables

Opening costs/pce for land-fillers

Operating costs/pce for manufacturer 1

Operating costs/pce for manufacturer 2

Operating costs/pce for manufacturer 3

Operating costs/pce for manufacturer 4

Operating costs/pce for leather goods brand dealer 1

Operating costs/pce for leather goods brand dealer 2

Operating costs/pce for leather goods brand dealer 3

Operating costs/pce for leather goods brand dealer 4

Operating costs/pce for leather goods brand retailer 1

Operating costs/pce for leather goods brand retailer 1

Operating costs/pce for leather goods brand retailer 2

Operating costs/pce for leather goods brand retailer 3

Operating costs/pce for leather goods brand retailer 4

Operating costs/pce for repair/service centre 1

Operating costs/pce for repair/service centre 2

Operating costs/pce for collector/dismantler/re-furbisher 1

Operating costs/pce for collector/dismantler/re-furbisher 2

Operating costs/pce for remanufacturer 1

Operating costs/pce for remanufacturer 2

Operating costs/pce for remanufacturer 3

Operating costs/pce for remanufacturer 4

Operating costs/pce for recyclers

Operating costs/pce for land fillers

Operating costs/pce for leather goods brand resellers

Transportation cost per kilometer/pce

Un-utilized capacity costs for manufacturer 1 / pce

Un-utilized capacity costs for manufacturer 2/ pce

Un-utilized capacity costs for manufacturer 3/ pce

Un-utilized capacity costs for manufacturer 4/ pce

Un-utilized capacity costs for Re-manufacturer 1 / pce

Un-utilized capacity costs for Re-manufacturer 2/ pce

Un-utilized capacity costs for Re-manufacturer 3/ pce

Un-utilized capacity costs for Re-manufacturer 4/ pce
Value

Rs. 60

Rs. 200

Rs. 230

Rs. 250

Rs. 240

Rs. 120

Rs. 130

Rs. 120

Rs. 140

Rs. 80

Rs. 80

Rs. 90

Rs. 80

Rs. 90

Rs. 70

Rs. 70

Rs. 100

Rs. 110

Rs. 120

Rs. 120

Rs. 130

Rs. 130

Rs. 60

Rs. 40

Rs. 100

Rs. 2.00

Rs. 220

Rs. 230

Rs. 250

Rs. 240

Rs. 120

Rs. 130

Rs. 150

Rs. 140 
The distances between different pairs of facilities or nodes and that of between different pairs of facilities and customers (first customers, second customers) are given in Appendix I. First, the mathematical model developed by Aravendan and Panneerselvam [1] was formulated for the leather goods industry case study using the data shown in Table 1, Table 2 and Appendix I. When it was solved using LINGO15 software, it has been found that the model did not give solution even after several hours of execution. The LINGO 15 software was run on MS Windows 7 Professional platform in a 64-bit operating system of Hewlett-Packard Lap Top Computer with a processor: Intel(R) Core(TM) i5-2430 CPU@2.40 GHz 2.40 GHz. with 4.00 GB installed memory (RAM) capacity.

The CLSCND problem of the case study has been then solved using HGA4 developed by Aravendan and Panneerselvam [2]. The sequential steps involved in implementing the best hybrid genetic algorithm (HGA4) are furnished below and the input data used in the algorithm are given in Table 1, Table 2 and Appendix I.

\section{Steps of Hybrid Genetic Algorithms}

The step-by-step processes which are executed for the implementation of the best hybrid genetic algorithm (HGA4) are presented here.

"Step 1: Feed the following inputs;

Number of Echelons= 11 (Leather Goods Manufacturers, Leather Goods Brand Dealers, Leather Goods Brand Retailers, First Customers, Repair Centers, Collector/Dismantler/Re-furbishers, Recyclers, Land fillers, Leather Goods Remanufacturers, Leather Goods Brand Resellers and Second Customers).

Maximum number of units /nodes in each stage from first to last stage (i.e. 4, 4, 4, 8, 2, 2, 2, 2, 4 , 2 and 4, respectively) as genes of the chromosome.

Maximum number of successive populations to be generated $(\mathrm{N})=50$.

Maximum number of Chromosomes in each population-population size $(\mathrm{L})=100$.

The Generation Count, GC $=1$.

Step 2: Apply the binary encoding method for the chromosomes to decide on the status (open or close) of the genes (units) in the Chromosomes.

Step 3: Generate a random initial population of L chromosomes (suitable solutions for the problem).

Let it be a larger population, $\mathrm{L}=100$.

Step 4: Evaluate the Fitness function $\mathrm{f}(\mathrm{x})$ of each chromosome in the initial population L. The fitness function is as used in the mathematical model proposed in this research work, which is as given below.

Fitness Function Value $($ FFV) $=$ OPC + OPRC + UCC + TC, where OPC = Opening Cost, OPRC = Operation Cost, UCC = Un-utilized Capacity Cost and TC $=$ Transportation cost. (The Transshipment Algorithm, which is a combination of VAM method and U-V method, is incorporated to evaluate the transshipment cost of the fitness function)

Step 5: Sort the population L by the objective function (fitness function) value in the ascending order, because it is a minimization problem.

Step 6: Apply Elite Count (say top 2) and Rank selection. Select a given percentage (say 30\%) from the top of the larger population $\mathrm{L}$ leaving the elite count, to form a sub-population $\mathrm{S}$.

Step 7: Randomly pickup any two unselected parent chromosomes from the sub-population S. Let them be the parents $\mathrm{x}$ and $\mathrm{y}$.

Step 8: Perform the crossover of the parents $\mathrm{x}$ and $\mathrm{y}$ to form their two new offspring $\mathrm{x}_{1}$ and $\mathrm{y}_{1}$ (Uniform crossover method is applied to form hybrid genetic algorithm, HGA4).

Step 9: Perform the mutation of each of the offspring $x_{1}$ and $y_{1}$ for a mutation probability $P_{m}\left(\right.$ say $\left.P_{m}=0.06\right)$.

Step 10: Evaluate the fitness function value of each of the offspring $\mathrm{x}_{1}$ and $\mathrm{y}_{1}$. (The Transshipment Algorithm, which is a combination of VAM and U-V algorithms, is incorporated in the fitness function to evaluate the transshipment cost of the fitness function).

Step 11: Replace the parent chromosomes $\mathrm{x}$ and $\mathrm{y}$ along with their fitness function values in the larger population $\mathrm{L}$ with offspring $\mathrm{x}_{1}$ and $\mathrm{y} 1$ along with their fitness function values, respectively. (Here, weak parent replacement method is applied to form hybrid genetic algorithm, HGA4)

Step 12: Repeat Step 7 to Step 11 until all the chromosomes in the sub-population S are selected to create offspring.

Step 13: Increase the Generation Count (GC) by 1, i.e. GC $=\mathrm{GC}+1$.

Step 14: If GC $\leq$ N, then go to Step 5, else go to Step 15 .

Step 15: Identify the chromosome in the larger population $\mathrm{L}$, which has the best fitness function value and 
print the corresponding results.

Step 16: Stop."

From the result obtained, it is found that the HGA4 is very efficient in providing the solution in terms of processing time and it provided the optimized solution value of $0.1880480 \mathrm{E}+09$ in just few seconds. The optimized flows of the solution thus obtained for the design of the closed loop supply chain network is illustrated in Figure 3.

\subsection{Results Discussion}

The closed loop supply chain network design problem of the fashion leather goods industry which deals with travel goods, luggage goods and leather goods is solved in this section with an objective to minimize the total cost of the entire network. The CLSC network design problem was attempted first with the mathematical model based on MINLP. As the solution was not obtained by the implementation of the mathematical model even after several hours of implementation in LINGO 15 optimization platform, the leather goods industry problem was solved using the best Hybrid Genetic Algorithm (HGA4) developed for the purpose. Thus the optimized solution has been obtained for the closed loop supply chain network design problem and finally the minimized total cost is presented along with the corresponding shipment pattern for the entire distribution network design of the fashion leather goods industry.

\section{Conclusion}

The research work considered the closed loop supply chain network design problem of the fashion leather goods industry with an objective of minimizing the total cost of the entire supply chain system. First, the mathematical model based on MINLP was implemented to get an optimum solution in a reasonable time period using the commercially available optimization software LINGO 15. As the mathematical model was not solved even after long hours of implementation, the best hybrid genetic algorithm was implemented in the next level to solve the problem of the fashion leather goods industry, in which the HGA4 has provided the solution within a few

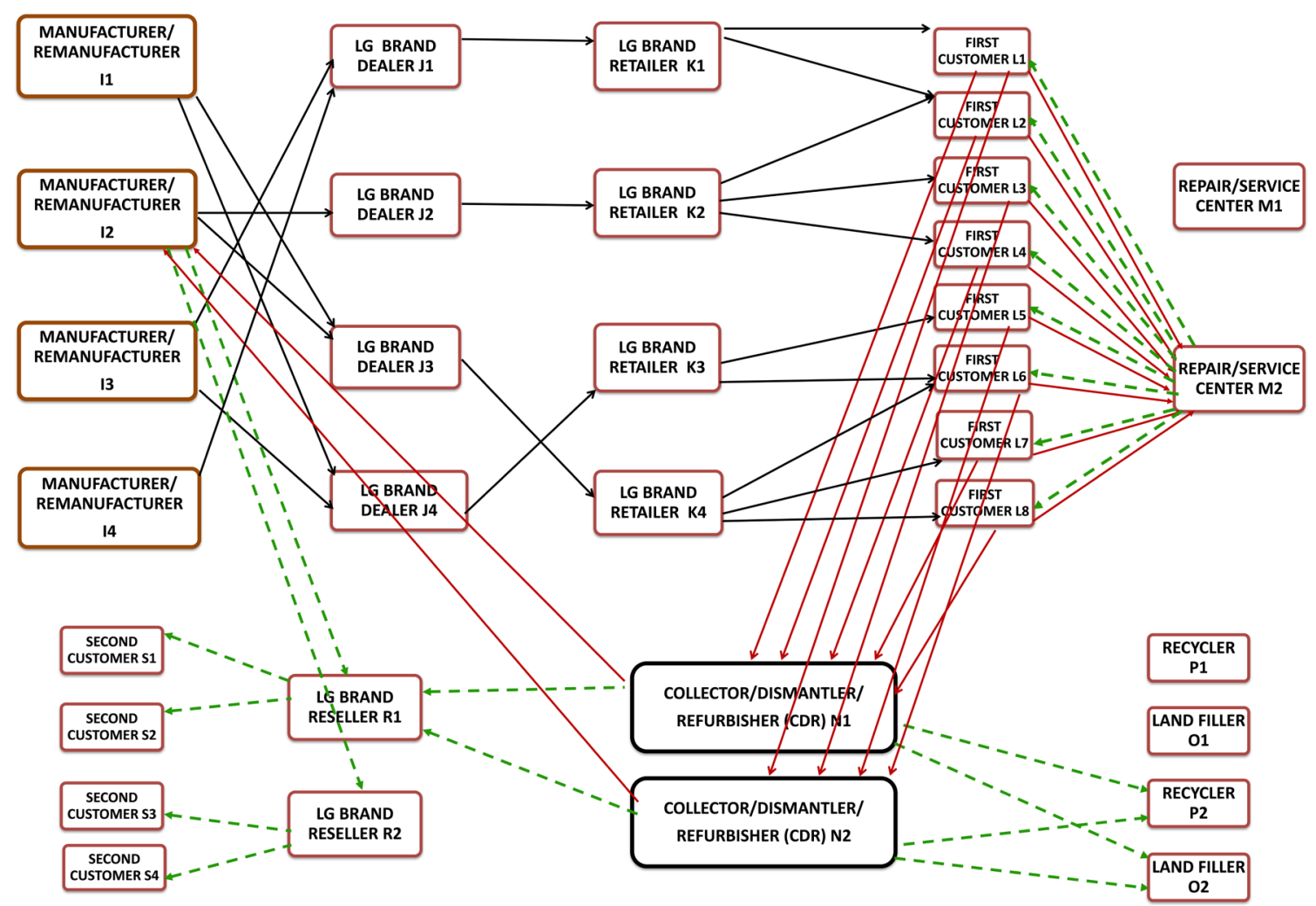

Figure 3. Optimized shipment flows in CLSCND model for the leather goods industry case study. 
seconds. It is assumed that the solution provided by HGA4 is the optimum solution or it will be nearer to the optimum solution for the CLSC network design problem of the fashion leather goods industry case considered in this research work. Thus, this research work has addressed the research gap identified in the literature, by solving closed loop supply chain network design problem of travel, luggage and leather goods industry which is combinatorial and NP-hard in nature and also a unique industry case which is not dealt by any other researcher in the past, by implementing the suitable hybrid genetic algorithm.

\section{Acknowledgements}

The authors convey their heartfelt thanks and sincere gratitude to the industries for their excellent cooperation and support by providing the requisite data for conducting this research work. The authors also profusely thank the anonymous reviewers for their constructive and valuable feedback which are incorporated in this paper.

\section{References}

[1] Aravendan, M. and Panneerselvam, R. (2014) An Integrated Multi-Echelon Model for a Sustainable Closed Loop Supply Chain Network Design. Intelligent Information Management, 6, 257-279. http://dx.doi.org/10.4236/iim.2014.66025

[2] Aravendan, M. and Panneerselvam, R. (2015) Development and Comparison of Hybrid Genetic Algorithms for Network Design Problem in Closed Loop Supply Chain. Intelligent Information Management, 7, 313-338. http://dx.doi.org/10.4236/iim.2015.76025

[3] Fleischmann, M., Krikke, H.R., Dekker, R. and Flapper, S.D.P. (2000) A Characterization of Logistics Networks for Product Recovery. Omega, 28, 653-666. http://dx.doi.org/10.1016/S0305-0483(00)00022-0

[4] Bruce, M., Daly, L. and Towers, N. (2004) Lean or Agile: A Solution for Supply Chain Management in the Textiles and Clothing Industry? International Journal of Operations \& Productions Management, 24, 151-170.

[5] Barnes, L. and Greenwood, G.L. (2006) Fast Fashioning the Supply Chain: Shaping the Research Agenda. Journal of Fashion Marketing and Management, 10, 259-271. http://dx.doi.org/10.1108/13612020610679259

[6] Li, X. and Olorunniwo, F. (2008) CS-90. An Exploration of Reverse Logistics Practices in Three Companies. Supply Chain Management: An International Journal, 13, 381-386.

[7] Ho, H.P.-Y. and Choi, T.-M. (2012) A Five-R Analysis for Sustainable Fashion Supply Chain Management in Hong Kong: A Case Analysis. Journal of Fashion Marketing and Management, 16, 161-175. http://dx.doi.org/10.1108/13612021211222815

[8] Nie, J., Huang, Z., Zhao, Y. and Shi, Y.(2013) Collective Recycling Responsibility in Closed-Loop Fashion Supply Chains with a Third Party: Financial Sharing or Physical Sharing? Mathematical Problems in Engineering, 2013, Article ID: 176130 .

[9] Ciarniene, R. and Vienazindiene, M. (2014) Management of Contemporary Fashion Industry: Characteristics and Challenges. Procedia-Social and Behavioral Sciences, 156, 63-68. 19th International Scientific Conference; Economics and Management 2014, ICEM 2014, 23-25 April 2014, Riga. http://dx.doi.org/10.1016/j.sbspro.2014.11.120

[10] Tokhmehchi, N., Makui, A. and Nezhad, S.S. (2015) A Hybrid Approach to Solve a Model of Closed-Loop Supply Chain. Mathematical Problems in Engineering, 2015, 1-18. http://dx.doi.org/10.1155/2015/179102

[11] Panneerselvam, R. (2006) Operations Research. PHI Learning, New Delhi.

[12] Panneerselvam, R. (2012) Design and Analysis of Algorithms. PHI Learning, New Delhi. 


\section{Appendix I}

Tables of distances between different pairs of facilities/nodes and customers in kilometers, used in mathematical model and HGA of leather goods industry case study

Table A1. Distances between manufacturers (I) and leather goods brand dealers (J) D1.

\begin{tabular}{rcccc}
\hline & $\begin{array}{c}\text { Leather Goods } \\
\text { Brand Dealer J1 }\end{array}$ & $\begin{array}{c}\text { Leather Goods } \\
\text { Brand Dealer J2 }\end{array}$ & $\begin{array}{c}\text { Leather Goods } \\
\text { Brand Dealer J3 }\end{array}$ & $\begin{array}{c}\text { Leather Goods } \\
\text { Brand Dealer J4 }\end{array}$ \\
\hline Manufacturer I1 & 7 & 16 & 25 & 27 \\
Manufacturer I2 & 12 & 5 & 16 & 19 \\
Manufacturer I3 & 37 & 29 & 13 & 10 \\
Manufacturer I4 & 35 & 24 & 11 & 9 \\
\hline
\end{tabular}

Table A2. Distances between leather goods brand dealers (J) and leather goods brand retailers (K) D2.

\begin{tabular}{ccccc}
\hline & $\begin{array}{c}\text { Leather Goods } \\
\text { Brand Retailer K1 }\end{array}$ & $\begin{array}{c}\text { Leather Goods } \\
\text { Brand Retailer K2 }\end{array}$ & $\begin{array}{c}\text { Leather Goods } \\
\text { Brand Retailer K3 }\end{array}$ & $\begin{array}{c}\text { Leather Goods } \\
\text { Brand Retailer K4 }\end{array}$ \\
\hline $\begin{array}{c}\text { Leather Goods } \\
\text { Brand Dealer J1 } \\
\text { Leather Goods } \\
\text { Brand Dealer J2 }\end{array}$ & 9 & 15 & 21 & 27 \\
Leather Goods \\
Brand Dealer J3 \\
Leather Goods \\
Brand Dealer J4
\end{tabular}

Table A3. Distances between leather goods brand retailers (K) and first customers FC (L) D3.

\begin{tabular}{ccccccccc}
\hline & FCL1 & FCL2 & FCL3 & FCL4 & FCL5 & FCL6 & FCL7 & FCL8 \\
\hline $\begin{array}{c}\text { Leather Goods } \\
\text { Brand Retailer K1 }\end{array}$ & 5 & 6 & 10 & 8 & 15 & 22 & 25 & 28 \\
$\begin{array}{c}\text { Leather Goods } \\
\text { Brand Retailer K2 }\end{array}$ & 13 & 6 & 7 & 5 & 14 & 22 & 21 & 30 \\
$\begin{array}{c}\text { Leather Goods } \\
\text { Brand Retailer K3 }\end{array}$ & 16 & 18 & 12 & 21 & 7 & 8 & 12 & 10 \\
$\begin{array}{c}\text { Leather Goods } \\
\text { Brand Retailer K4 }\end{array}$ & 18 & 20 & 25 & 19 & 6 & 9 & 10 & 7 \\
\hline
\end{tabular}

Table A4. Distances between first customers FC (L) and repair centers (M) D4 = D5.

\begin{tabular}{ccccccccc} 
& FCL1 & FCL2 & FCL3 & FCL4 & FCL5 & FCL6 & FCL7 & FCL8 \\
\hline Repair Center M1 & 5 & 4 & 13 & 6 & 17 & 27 & 29 & 24 \\
Repair Center M2 & 6 & 7 & 8 & 10 & 10 & 20 & 31 & 26 \\
\hline
\end{tabular}

Table A5. Distances between first customers FC (L) and collectors/dismantlers/re-furbishers CDR (N) D6.

\begin{tabular}{cccccccccc}
\hline & FCL1 & FCL2 & FCL3 & FCL4 & FCL5 & FCL6 & FCL7 & FCL8 \\
\hline CDR N1 & 6 & 5 & 11 & 9 & 16 & 25 & 26 & 29 \\
CDR N2 & 6 & 7 & 8 & 10 & 10 & 20 & 21 & 24 \\
\hline
\end{tabular}


Table A6. Distances between first customers FC (L) and leather goods brand retailers (K) D7.

\begin{tabular}{|ccccccccc}
\hline & FCL1 & FCL2 & FCL3 & FCL4 & FCL5 & FCL6 & FCL7 & FCL8 \\
\hline Leather Goods Brand Retailer K1 & 5 & 6 & 10 & 8 & 15 & 22 & 25 & 28 \\
Leather Goods Brand Retailer K2 & 13 & 6 & 7 & 5 & 14 & 22 & 21 & 30 \\
Leather Goods Brand Retailer K3 & 16 & 18 & 12 & 21 & 7 & 8 & 12 & 10 \\
Leather Goods Brand Retailer K4 & 18 & 20 & 25 & 19 & 6 & 9 & 10 & 7 \\
\hline
\end{tabular}

Table A7. Distances between leather goods brand retailers (K) and collectors/dismantlers/re-furbishers CDR (N) D8.

\begin{tabular}{ccccc}
\hline & $\begin{array}{c}\text { Leather Goods } \\
\text { Brand Retailer K1 }\end{array}$ & $\begin{array}{c}\text { Leather Goods } \\
\text { Brand Retailer K2 }\end{array}$ & $\begin{array}{c}\text { Leather Goods } \\
\text { Brand Retailer K3 }\end{array}$ & $\begin{array}{c}\text { Leather Goods } \\
\text { Brand Retailer K4 }\end{array}$ \\
\hline CDR N1 & 7 & 8 & 9 & 7 \\
CDR N2 & 9 & 6 & 10 & 8 \\
\hline
\end{tabular}

Table A8. Distances between collectors/dismantlers/re-furbishers CDR (N) and land fillers (O) D9.

\begin{tabular}{ccc}
\hline & Land Filler O1 & Land Filler O2 \\
\hline CDR N1 & 16 & 12 \\
CDR N2 & 19 & 11 \\
\hline
\end{tabular}

Table A9. Distances between collectors/dismantlers/re-furbishers CDR (N) and recycler (P) D10.

\begin{tabular}{ccc}
\hline & Recycler P1 & Recycler P2 \\
\hline CDR N1 & 13 & 12 \\
CDR N2 & 18 & 11 \\
\hline
\end{tabular}

Table A10. Distances between collectors/dismantlers/re-furbishers CDR (N) and leather goods brand resellers (R) D11.

\begin{tabular}{ccc}
\hline & Leather Goods Brand Reseller R1 & Leather Goods Brand Reseller R2 \\
\hline CDR N1 & 6 & 4 \\
CDR N2 & 6 & 3 \\
\hline
\end{tabular}

Table A11. Distances between collectors/dismantlers/re-furbishers CDR (N) and remanufacturers (I) D12.

\begin{tabular}{ccccc}
\hline & Remanufacturer I1 & Remanufacturer I2 & Remanufacturer I3 & Remanufacturer I4 \\
\hline CDR N1 & 14 & 10 & 33 & 25 \\
CDR N2 & 16 & 11 & 28 & 20 \\
\hline
\end{tabular}

Table A12. Distances between remanufacturers (I) and leather goods brand resellers (R) D13.

\begin{tabular}{lcc}
\hline & Leather Goods Brand Reseller R1 & Leather Goods Brand Reseller R2 \\
Remanufacturer I1 & 11 & 16 \\
Remanufacturer I2 & 12 & 30 \\
Remanufacturer I3 & 27 & 22 \\
Remanufacturer I4 & 23 \\
\hline
\end{tabular}


Table A13. Distances between leather goods brand resellers (R) and second customers SC (S) D14.

\begin{tabular}{ccccc}
\hline & SC S1 & SC S2 & SC S3 & SC S4 \\
\hline Reseller R1 & 7 & 8 & 13 & 15 \\
Reseller R2 & 11 & 12 & 10 & 13 \\
\hline
\end{tabular}

Submit or recommend next manuscript to SCIRP and we will provide best service for you:

Accepting pre-submission inquiries through Email, Facebook, Linkedin, Twitter, etc A wide selection of journals (inclusive of 9 subjects, more than 200 journals)

Providing a 24-hour high-quality service

User-friendly online submission system

Fair and swift peer-review system

Efficient typesetting and proofreading procedure

Display of the result of downloads and visits, as well as the number of cited articles

Maximum dissemination of your research work

Submit your manuscript at: http://papersubmission.scirp.org/ 